\title{
Valorization of Polyolefins Dissolved in Light Cycle Oil over HY Zeolites under Fluid Catalytic Cracking Unit Conditions
}

\author{
J osé M. Arandes,* J avier Ereña, and J avier Bilbao \\ Departamento de Ingeniería Química, Universidad del País Vasco, Apartado 644, 48080 Bil bao, Spain \\ Danilo López-Valerio \\ Facultad de Ingeniería Química, Universidad Nacional de Ingeniería, Apartado 5595, Managua, Nicaragua
}

\begin{abstract}
Gabriela De la Puente
I nstituto de I nvestigaciones en Catálisis y Petroquímica, I NCAPE (FIQ, UNL-CONICET), Santiago del Estero 2654, 3000 Santa Fe, Argentina
\end{abstract}

\begin{abstract}
A study has been made of the valorization of polyolefins, PE (polyethylene) and PP (polypropylene), dissolved in LCO [light cycle oil obtained as a product stream in a fluid catalytic cracking (FCC) unit] by their cracking on three catalysts prepared based on HY zeolites of different acidity and different porous structure. The reaction has been studied in the $450-550{ }^{\circ} \mathrm{C}$ range and under conditions similar to those of the FCC. The determining factor in the performance of the catalyst is the accessibility of the acid sites by the dissolved macromolecular chains, where a moderate acidity of the zeolite is sufficient. Whereas a feed of dissolved PE contributes to a decrease of the yield of coke with respect to that corresponding to the cracking of LCO, a feed of PP increases the yield of coke. The optimum temperature for maximizing the yield of gasoline, and minimizing that of coke, is $450^{\circ} \mathrm{C}$. The gasoline fraction $\left(\mathrm{C}_{5}-\mathrm{C}_{12}\right)$ is mainly aromatic with $\mathrm{C}_{8+}$ components. The stream of gaseous products is largely made up of propylene and butenes.
\end{abstract}

\section{Introduction}

The valorization of postconsumer plastics is a challenge for developed countries in view of the high production of these materials ( 20 million tonnes in the U.S., 15 tonnes in Europe, and 15 tonnes in J apan in the year 2001), with an estimated annual increase of $4 \%$. Thermal pyrolysis is considered to bean appropriate solution for the treatment of all plastics overall and produces good yields of feedstock and fuel. ${ }^{1,2}$ Given the good performance of the fluidized bed (uniform coating of sand particles with fused plastic, high heat transfer rate, and short resi dence time of the gas stream), plants of different scale based on this technology have been tested for the last 20 years. ${ }^{3-9}$

Innovative reactors have been proposed in order to solve the problems of this process in fluidized reactors. These problems are, among others, stickiness of the sand particles coated with plastic and limitation to heat transfer in the plastic. Regarding the new reactors, the following are worth mentioning: the fluidized-bed reactor with internal circulation, ${ }^{10,11}$ the rotary conical reactor, ${ }^{12,13}$ the circulated-sphere reactor, ${ }^{14,15}$ a reactor with stirred-heat medium particles, 16 the continuous screw kiln,17 and the conical spouted bed.18,19 The viability of these reactors is still to be proven at large scale.

Likewise, the use of catalysts in the fluidized-bed reactor has been studied. ${ }^{9,20-22}$ Catalytic pyrolysis aims to lower the pyrolysis temperature (which minimizes energy requirements) and to improve the quality of the product, either by increasing the yield of monomers or

* To whom correspondence should be addressed. Tel.: 34 94-6012511. Fax: 34-94-4648500. E-mail: iqparesj@g.ehu.es. by obtaining a liquid product with a composition similar to that of a quality fuel, which may be used as an automotive fuel.

Nevertheless, as yet there is no well-defined technological solution that may be carried out in a profitable manner at large scale. To avoid the economic implications that involve the development of a new design of the industrial process and the marketing of the new product, interesting strategies for the treatment of postconsumer plastics are those that use existing industrial technologies, such as fluid catalytic cracking (FCC). This process was conceived for obtaining gasoline and ol efins from vacuum gas oil, but in the past decades, it has undergone a considerable technological development. The present trends in this development are geared toward an increase in the versatility of process conditions, with the aim of allowing for the treatment of raw materials of different composition. ${ }^{23}$ Based on this philosophy, the incorporation of plastics into the FCC does not require any significant modifications in the technol ogy.

The use of the FCC for valorizing plastics has been studied in the literature, and two alternative routes have been proposed: (1) the catalytic transformation of the wax obtained as the primary product in the thermal pyrolysis of polyolefins;24-27 (2) the catalytic transformation of the plastic waste by dissolving it in the feed of the FCC. ${ }^{28}$ The second route has the advantage that it does not require the pyrolysis unit and, moreover, it is applicable to unclassified plastic wastes [with the exception of poly(vinyl chloride), which must be eliminated by a prior treatment of dechlorination], which may be dissolved at the collection point and subsequently transported to the refinery. Furthermore, if a 
Table 1. Characterization Data for LCO

\begin{tabular}{|c|c|c|c|c|}
\hline $\begin{array}{l}\text { density }\left(15^{\circ} \mathrm{C}\right), \mathrm{g} \mathrm{cm}^{-3} \\
\text { sulfur, wt } \%\end{array}$ & $\begin{array}{l}0.91 \\
0.60\end{array}$ & & $\begin{array}{l}\text { viscosity, } 100^{\circ} \mathrm{C} \text { cSt } \\
\text { flash point, }{ }^{\circ} \mathrm{C}\end{array}$ & 93 \\
\hline $\begin{array}{c}\text { simulated } \\
\text { distillation, wt \% }\end{array}$ & ${ }^{\circ} \mathrm{C}$ & & n, wt \% & ${ }^{\circ} \mathrm{C}$ \\
\hline $\begin{array}{l}\text { IP } \\
5 \\
10 \\
20 \\
30 \\
40 \\
50\end{array}$ & $\begin{array}{l}125 \\
175 \\
187 \\
203 \\
219 \\
231 \\
249\end{array}$ & & $\begin{array}{l}60 \\
70 \\
80 \\
90 \\
95 \\
\text { EP }\end{array}$ & $\begin{array}{l}264 \\
282 \\
302 \\
329 \\
350 \\
390\end{array}$ \\
\hline composition & & wt $\%$ & composition & wt \\
\hline $\begin{array}{l}\text { saturates } \\
\text { paraffins } \mathrm{C}_{n} \mathrm{H}_{2 n+2} \\
\text { monocycloparaffins } \mathrm{C} \\
\text { dicycloparaffins } \mathrm{C}_{n} \mathrm{H}_{2} \\
\text { tricycl oparaffins } \mathrm{C}_{n} \mathrm{H}_{2} \\
\text { tetracycloparaffins } \mathrm{C}_{n}\end{array}$ & $\mathrm{H}_{2 \mathrm{n}}$ & $\begin{array}{r}20.7 \\
7.9 \\
5.6 \\
2.7 \\
4.5 \\
0.0\end{array}$ & $\begin{array}{l}\text { aromatics } \\
\text { monocyclic } \\
\text { dicyclic } \\
\text { tricyclic } \\
\text { sulfur compounds } \\
\text { thiophenes } \\
\text { benzothiophenes }\end{array}$ & $\begin{array}{r}66.9 \\
33.0 \\
33.1 \\
0.8 \\
12.4 \\
0.4 \\
12.0\end{array}$ \\
\hline
\end{tabular}

residual stream is used as the solvent, its valorization will also be achieved. In a previous paper by Arandes et al., good yields of gasoline have been obtained following this strategy for val orizing polypropylene and polystyrene with commercial cracking catalysts. ${ }^{29}$

A feature of the FCC is its continuous technological adaptation to new feeds and to the need for new products, which are under changing market requirements (as is the case of light ol efins) and environmental regulations (as is the case of gasol ine formulations and limitations in the content of ol efins and aromatics). ${ }^{30}$ Consequently, the composition and properties of the catalyst are being studied in order to achieve the aforementioned objectives.

In the catalytic transformation of polyolefins in FCC units, the selection of the optimum catalyst is crucial, as may deduced from the studies of catalytic pyrolysis in different reactors, in which conversion and selectivity to aromatics and olefins in the product stream are conditioned by the nature and acid strength of the sites and by the porous structure of the catalyst. $22,31,32$ In this paper, the performance of different $\mathrm{HY}$ zeolites has been studied in the valorization of polyolefins, which are approximately $50 \mathrm{wt} \%$ of the total plastic content of municipal solid waste. The zeol ites have been prepared with different acidities and with different porous structures, with the aim of determining the effect of these properties in the yield and composition of products. The reaction conditions are similar to those of the FCC riser reactor.

\section{Experimental Section}

Feed. The plastics studied are polyethylene (PE) of low density (MW, $9.22 \times 10^{4}$; polydispersity, 5.1) and polypropylene (PP; MW, $12 \times 10^{4}$; polydispersity, 5.0) supplied by Dow Chemical SA. The degradation ranges have been determined by means of thermogravimetric analysis (Setaram TAG 24): $430-500{ }^{\circ} \mathrm{C}$ for PE and $410-480^{\circ} \mathrm{C}$ for PP. The temperature corresponding to the maximum rate of weight loss of these two materials is $460{ }^{\circ} \mathrm{C}$. The plastic diluent agent was a light cycle oil (LCO) whose composition is shown in Table 1. A total of $30 \mathrm{wt} \%$ of LCO corresponds to hydrocarbons with a boiling point within the range of the gasoline pool $\left(C_{5}-C_{12}\right)$. This solvent has been chosen because it corresponds to a product stream of a commercial FCC unit and, consequently, it is of low reactivity in the cracking. This is interesting in order to separately identify its reactivity from that of the dissolved plastic. The aromatic nature of the LCO is similar to that expected for the products of polyolefin catalytic cracking, which means that the synergistic effect of cracking LCO and plastic constituents will be minimum. The dissolution of the plastics in LCO was carried out in a stirred tank at $100^{\circ} \mathrm{C}$. The feeds were made up of PE at $10 \mathrm{wt}$ $\%$ and of PP at 5 wt \% (a greater concentration of PP meant very high viscosity and, consequently, problems of solidification in the reactor injection system).

Catalysts. Three catalysts have been prepared based on a commercial HY zeol ite from Engel hard. This zeol ite has been subjected to three different treatments, with the aim of obtaining different porous structures and surface acidity levels. The HY zeolite named $A$ has been obtained by ion exchange with ammonium ions in order to reduce the content of $\mathrm{Na}$. The zeol ite is stirred in a dissolution of $2.5 \mathrm{~N} \mathrm{NH}_{4} \mathrm{NO}_{3}$ at $80{ }^{\circ} \mathrm{C}$, where the solution/zeolite mass ratio is 10 . Subsequently, the steps of filtration and rinsing with distilled water are carried out, and the product is calcined following a sequence of programmed temperature up to $520^{\circ} \mathrm{C}$ and then maintenance of this temperature for $4 \mathrm{~h}$. The previous steps of ion exchange and subsequent calcination are repeated three times in order to obtain a reproducible final structure.

The HY zeolite named B is obtained by dealumination of the commercial zeolite. The metathesis reactions involving removal of $\mathrm{Al}^{3+}$ in $\mathrm{T}$ sites followed by $\mathrm{Si}^{4+}$ substitution using aqueous ammonium hexafluorosilicate, $\left(\mathrm{NH}_{4}\right)_{2} \mathrm{SiF}_{6}$, are well-documented. ${ }^{33}$

The HY zeolite named $\mathrm{C}$ is obtained by steaming the commercial zeolite in a fluidized-bed reactor of $2.7 \mathrm{~cm}$ internal diameter made of refractory steel. The treatment consists of successive steps of steaming at 200, 540 , and $820^{\circ} \mathrm{C}$, each one for $3 \mathrm{~h}$. Between the second and third steps, a treatment of ion exchange is carried out in a solution of $\mathrm{NH}_{4} \mathrm{NO}_{3}$ (such as that aforementioned for zeolite A but without the final calcination step).

The final catalysts, as they are to be used in the cracking reaction, are obtained by incorporating each one of these zeolites into a silica matrix. The zeolite content is 25 wt \%. The silica source is $\mathrm{Na}_{2} \mathrm{SiO}_{3} \cdot 12 \mathrm{H}_{2} \mathrm{O}$, where the zeolite is dispersed. The gel is formed by ammonia addition, extrusion, two-step drying (at room temperature and in an oven at $110^{\circ} \mathrm{C}$ ), and finally calcination in a nitrogen stream at $650^{\circ} \mathrm{C}$ for $2 \mathrm{~h}$. The catalysts have been named $\mathrm{A}-\mathrm{C}$ and correspond to the HY zeolites with the same denominations and whose preparation has been explained above.

The more relevant physical properties of the zeolites are set out in Table 2 . The porous structure and the surface area (Brunauer-Emmett-Teller, BET) have been characterized from the isotherms of adsorptiondesorption of $\mathrm{N}_{2}$ carried out in an ASAP 2000 from Micromeritics. The micropores of the catalyst correspond to those of the HY zeolite. The silica matrix of the catalyst has an exclusively mesoporous structure with pores of diameter between 30 and $300 \AA$. The effect of the silica matrix on the step of catalytic cracking is that of dilution of the catalyst and of facilitating the access of the reactants into the zeolite crystals located within the matrix. It must be taken into account that, except zeolite C, which has a mesopore volume of $0.21 \mathrm{~g} \mathrm{~cm}^{-3}$, 
Table 2. Properties of the HY Zeolites

\begin{tabular}{|c|c|c|c|c|c|c|c|c|c|}
\hline zeolite & $\begin{array}{l}\mathrm{Si} / \mathrm{Al} \\
\mathrm{ratio}\end{array}$ & $\begin{array}{c}\text { acidity, } \\
\mathrm{mmol} \text { of } \mathrm{NH}_{3} \mathrm{~g}^{-1}\end{array}$ & $\begin{array}{l}\text { Brönsted/ } \\
\text { Lewis ratio }\end{array}$ & $\begin{array}{l}\text { BET surface } \\
\text { area, } \mathrm{m}^{2} \mathrm{~g}^{-1}\end{array}$ & $\begin{array}{l}\text { micropore } \\
\text { surface, } \\
\mathrm{m}^{2} \mathrm{~g}^{-1}\end{array}$ & $\begin{array}{l}\text { mesopore } \\
\text { volume, } \\
\mathrm{cm}^{3} \mathrm{~g}^{-1}\end{array}$ & $\begin{array}{l}\text { micropore } \\
\text { volume, } \\
\mathrm{cm}^{3} \mathrm{~g}^{-1}\end{array}$ & $\begin{array}{c}\text { average } \\
\text { micropore } \\
\text { diameter, } \AA\end{array}$ & $\begin{array}{c}\text { average } \\
\text { mesopore } \\
\text { diameter, } \AA\end{array}$ \\
\hline untreated & 6.4 & 0.15 & 3.55 & 934 & 802 & 0.03 & 0.31 & 8.8 & \\
\hline A & 7.8 & 0.72 & 3.68 & 1017 & 844 & 0.03 & 0.33 & 9.3 & \\
\hline B & 8.6 & 0.88 & 3.83 & 928 & 788 & 0.03 & 0.30 & 9.2 & \\
\hline C & 18.6 & 0.20 & 2.57 & 432 & 332 & 0.21 & 0.13 & 9.9 & 40 \\
\hline
\end{tabular}

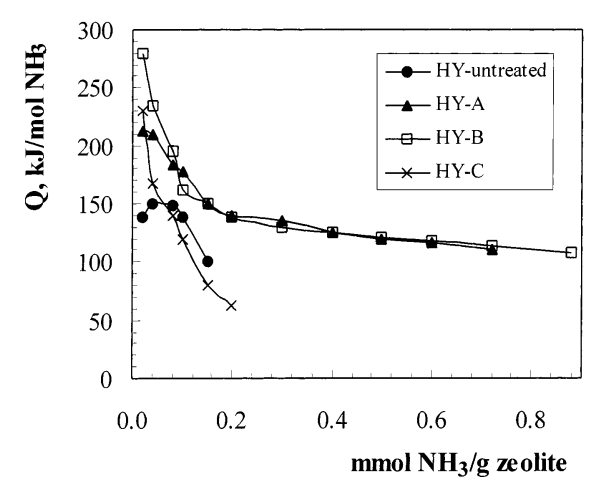

Figure 1. Acidity strength distribution of the catalysts studied, determined by differential adsorption of $\mathrm{NH}_{3}$ at $150{ }^{\circ} \mathrm{C}$.

the others are exclusively mesoporous, with a small mesopore volume of $0.03 \mathrm{~cm}^{3} \mathrm{~g}^{-1}$. Nevertheless, the role of the matrix in thermal cracking is important. Moreover, the differences in the micropore diameter of the zeolites in Table 2 are not significant and may be due to the experimental error introduced by using the same parameters (those of the HY zeolites) in the software of the measuring equipment.

The studies of acidity have consisted of (1) the determination of the Brönsted/Lewis sites ratio, Table 2 , by analyzing the FTIR spectra of adsorption of pyridine at $250^{\circ} \mathrm{C}$ and by ascertaining the ratio between the intensity of the bands corresponding to 1550 $\mathrm{cm}^{-1}$ (B-pyridine) and $1455 \mathrm{~cm}^{-1}$ (L-pyridine) [this study has been carried out by means of in situ FTIR spectroscopy in a catalytic chamber (Spectra Tech) connected in series with the FTIR spectrophotometer (Nicolet 740 SX) $]^{34}$ and (2) the analysis of acid strength distribution, Figure 1, and total acidity, Table 2, by differential adsorption of $\mathrm{NH}_{3}$ [this has been carried out in a differential scanning calorimeter (Setaram DSC 111) online with a Hewlett-Packard 6890 gas chromatograph; the cal orimeter is used to evaluate the adsorption heat (heat associated with the neutralization of acidic sites) of pulses of the base (at $150{ }^{\circ} \mathrm{C}$ ), and the chromatograph is used to assess the amount of base adsorbed]. 35

Figure 1 shows the important effect of the treatments applied to the zeolite on its surface acidity. The ion exchange (HY zeol ite A) generates a higher number of sites than the original zeolite. Furthermore, the sites formed are more acidic, with an adsorption heat between 120 and $200 \mathrm{~kJ}\left(\mathrm{~mol} \text { of } \mathrm{NH}_{3}\right)^{-1}$. The chemical dealumination ( $\mathrm{HY}$ zeolite B) produces, on the one hand, strongly acidic sites with an adsorption heat higher than $200 \mathrm{~kJ}\left(\mathrm{~mol} \text { of } \mathrm{NH}_{3}\right)^{-1}$ and, on the other hand, moderately acidic sites with an adsorption heat of around 120 $\mathrm{kJ}\left(\mathrm{mol} \text { of } \mathrm{NH}_{3}\right)^{-1}$. The generation of strongly acidic sites involves an increase in the Brönsted/Lewis ratio over that of zeolite A, Table 2 .

Dealumination by steaming (HY zeolite $\mathrm{C}$ ) causes a severe deterioration of the acid structure, and only a small fraction of sites maintains an acceptable $\mathrm{NH}_{3}$ adsorption capacity. This deterioration in acidity involves a significant decrease in the Brönsted/Lewis ratio, Table 2 .

It has been proven that the acidity of the catalysts prepared based on the three zeolites is almost equal to that of the pure zeolites, which is evidence that the silica matrix has no significant acidity. Besides, a silica gel has been prepared independently and an absence of acidity has been verified by means of the aforementioned techniques.

Reaction Equipment. In order for the catalytic cracking results to be of interest as a test reaction of what happens in the industrial FCC unit, the experiments must be carried out under conditions similar to those of the industrial riser. ${ }^{36}$ The equipment used in this work is a reactor riser simulator, Figure 2. It is an internal recycle reactor designed for catalytic cracking and has been previously described. ${ }^{37}$ I ts outstanding features are (1) a capability for operating with low and precise values of contact time in the range $1-10 \mathrm{~s}$ and (2) a suitable feed-catalyst contact because the reaction occurs in dilutefluidized-bed regime with a perfect mix for the catalyst and for the reaction mixture. The catalyst is in a basket, and the gases circulate through the basket impelled by a turbine located in the upper part. At zero time, the established amount of feed is injected and a timer is activated. Once the programmed time has elapsed, a valve is opened and the reaction products pass to a vacuum chamber thermostated at 300 ${ }^{\circ} \mathrm{C}$. These products are sent through a thermostated line to a gas chromatograph by means of a six-port valve. In previous papers, the excellent behavior of this reactor for kinetic studies of catalytic cracking has been proven. 38,39

The runs have been carried out at $1 \mathrm{~atm}$, in the $450-550{ }^{\circ} \mathrm{C}$ range, with a catalyst/feed ratio of $\mathrm{C} / \mathrm{O}=$ 6 by weight $(0.75 \mathrm{~g}$ of catalyst and $0.125 \mathrm{~g}$ of blend) and with a value of contact time of $3 \mathrm{~s}$. These conditions correspond to those of industrial FCC units. The contact time established is lower because the activity of the catalysts studied here, given their greater acidity, is expected to be higher than that corresponding to an equilibrated FCC catalyst, which has a very low acidity. ${ }^{29}$ The low value of residence time used minimizes the contribution of thermal cracking and the reactivity of the catalytic cracking products.

Product Analysis. Product analysis has been carried out by means of a device for reaction product sampling connected to a Hewlett-Packard 6890 chromatograph. The sampling is activated by a timer that controls the desired value of the contact time.

Product identification was carried out online by GC-FTIR, using a Nicolet/Aldrich library, by means of a FTIR Nicol et 740 SX spectrophotometer connected to a Hewlett-Packard 5890 II chromatograph. The results were verified by GC-MS (HP 6890-MS engine with el ectronic ionization). The product stream of the riser simulator was analyzed online with either MS or FTIR. 

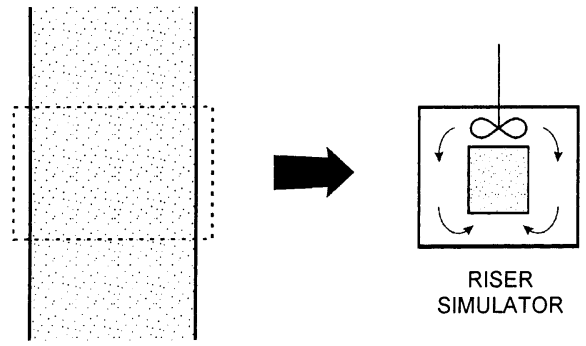

IDEAL RISER

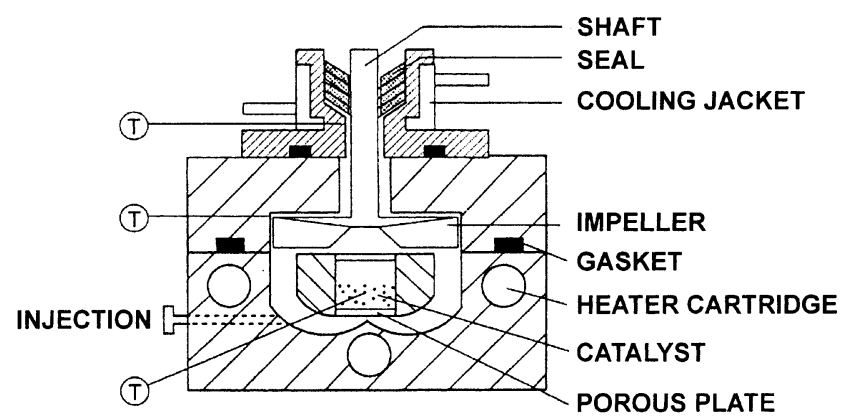

Figure 2. Scheme of the reactor.

Table 3. Results (in wt \%) of Conversion and Yields of Dry Gases $\left(C_{1}\right.$ and $\left.C_{2}\right)$, LPG $\left(C_{3}\right.$ and $\left.C_{4}\right)$, Gasoline $\left(C_{5}-C_{12}\right)$, and Coke for the Feeds of LCO, PE/LCO, and PP/LCO and for the Three Catalysts

\begin{tabular}{|c|c|c|c|c|c|c|c|}
\hline feedstock & catalyst & $\mathrm{T},{ }^{\circ} \mathrm{C}$ & $\begin{array}{c}\text { conversion, } \\
\text { wt \% }\end{array}$ & $\begin{array}{l}\mathrm{C}_{1} \text { and } \mathrm{C}_{2} \\
\text { gases, wt \% }\end{array}$ & $\begin{array}{c}\mathrm{C}_{3} \text { and } \mathrm{C}_{4} \\
\text { gases, wt \% }\end{array}$ & $\begin{array}{c}\text { gasoline }\left(C_{5}-C_{12}\right) \text {, } \\
\text { wt } \%\end{array}$ & $\begin{array}{l}\text { coke, } \\
\text { wt \% }\end{array}$ \\
\hline \multirow[t]{4}{*}{ LCO } & $A$ & 450 & 56.75 & 0.19 & 1.24 & 48.60 & 6.72 \\
\hline & & 500 & 56.78 & 0.52 & 2.09 & 47.27 & 6.90 \\
\hline & & 525 & 56.95 & 0.69 & 3.27 & 45.92 & 7.07 \\
\hline & & 550 & 57.30 & 1.43 & 3.87 & 44.86 & 7.14 \\
\hline \multirow[t]{4}{*}{ LCO } & B & 450 & 58.63 & 0.29 & 2.62 & 46.48 & 9.24 \\
\hline & & 500 & 61.24 & 0.97 & 4.23 & 45.83 & 10.21 \\
\hline & & 525 & 61.69 & 1.04 & 4.47 & 45.02 & 11.16 \\
\hline & & 550 & 61.90 & 1.43 & 4.68 & 42.81 & 12.98 \\
\hline \multirow[t]{4}{*}{ LCO } & C & 450 & 55.38 & 0.49 & 3.62 & 45.59 & 5.68 \\
\hline & & 500 & 55.77 & 0.55 & 3.87 & 45.33 & 6.02 \\
\hline & & 525 & 57.26 & 1.01 & 4.48 & 45.09 & 6.68 \\
\hline & & 550 & 58.35 & 1.79 & 5.27 & 44.02 & 7.27 \\
\hline \multirow[t]{4}{*}{ PE/LCO } & A & 450 & 54.44 & 0.37 & 1.68 & 49.27 & 3.12 \\
\hline & & 500 & 55.38 & 0.38 & 2.29 & 47.25 & 5.46 \\
\hline & & 525 & 55.84 & 0.66 & 2.89 & 45.66 & 6.63 \\
\hline & & 550 & 57.60 & 1.01 & 3.57 & 45.28 & 7.74 \\
\hline \multirow[t]{4}{*}{ PE/LCO } & B & 450 & 60.30 & 0.47 & 3.67 & 46.62 & 9.54 \\
\hline & & 500 & 60.57 & 0.66 & 4.41 & 45.41 & 10.09 \\
\hline & & 525 & 61.08 & 1.17 & 4.51 & 44.78 & 10.62 \\
\hline & & 550 & 62.05 & 1.75 & 6.21 & 42.52 & 11.57 \\
\hline \multirow[t]{4}{*}{ PE/LCO } & C & 450 & 57.93 & 0.42 & 2.51 & 49.57 & 5.43 \\
\hline & & 500 & 57.95 & 0.55 & 3.37 & 47.61 & 6.42 \\
\hline & & 525 & 58.04 & 0.73 & 4.03 & 46.20 & 7.08 \\
\hline & & 550 & 59.03 & 1.37 & 4.74 & 45.18 & 7.74 \\
\hline \multirow[t]{4}{*}{ PP/LCO } & A & 450 & 55.19 & 0.17 & 2.18 & 45.37 & 7.47 \\
\hline & & 500 & 56.40 & 0.57 & 3.37 & 44.49 & 7.97 \\
\hline & & 525 & 57.07 & 0.94 & 4.21 & 43.46 & 8.46 \\
\hline & & 550 & 58.19 & 1.59 & 4.34 & 42.90 & 9.36 \\
\hline \multirow[t]{4}{*}{ PP/LCO } & B & 450 & 54.74 & 0.53 & 3.61 & 42.21 & 8.39 \\
\hline & & 500 & 58.40 & 1.11 & 4.93 & 41.35 & 11.01 \\
\hline & & 525 & 65.01 & 2.06 & 7.12 & 41.21 & 14.62 \\
\hline & & 550 & 68.33 & 2.65 & 7.32 & 40.68 & 17.68 \\
\hline \multirow{4}{*}{ PP/LCO } & C & 450 & 52.23 & 0.24 & 2.36 & 44.89 & 4.74 \\
\hline & & 500 & 55.95 & 0.84 & 4.53 & 44.61 & 5.97 \\
\hline & & 525 & 58.10 & 1.40 & 5.77 & 43.73 & 7.20 \\
\hline & & 550 & 61.59 & 2.70 & 6.50 & 42.63 & 9.76 \\
\hline
\end{tabular}

To check and assign the retention times in the chromatographic analysis of compounds in the $\mathrm{C}_{5}-\mathrm{C}_{12}$ range, pure compounds and mixtures were used as standards. The assignation of the retention times of the components of the gasoline lump has been carried out by using Alphagaz PIANO (Air Liquide) calibration standards, which consist of 19 paraffinic, 35 isoparaffinic, 39 aromatic, 30 naphthenic, and 25 olefinic components. The amount of $\left(\mathrm{C}_{5}-\mathrm{C}_{12}\right)$ lump has been determined as that corresponding to the components with boiling points between those of $n-C_{5}$ paraffins (n-pentane) and $\mathrm{n}-\mathrm{C}_{12}$ (n-dodecane).

The coke deposited on the catalyst was measured by thermogravimetric analysis in a Setaram TAG 24 thermoanalyzer. The deactivated catalyst from the reactor is dried at $110{ }^{\circ} \mathrm{C}$ in a nitrogen stream and is subsequently subjected to combustion with air at a programmed temperature ramp $\left(5^{\circ} \mathrm{C} \mathrm{min}^{-1}\right)$ up to $700^{\circ} \mathrm{C}$.

\section{Results}

Conversion and Yields. The conversion is defined in weight percent and calculated as the sum of the yields in weight of gases $\left(C_{1}-C_{4}\right)$, gasoline $\left(C_{5}-C_{12}\right)$, and coke. Each yield is calculated as

$$
\text { yield of lump } i=\frac{\text { mass of lump } i}{\text { total mass in the feed }} \times 100
$$

Table 3 shows the results of conversion and the yiel ds of dry gases $\left(C_{1}\right.$ and $\left.C_{2}\right)$, LPG $\left(C_{3}\right.$ and $\left.C_{4}\right)$, gasoline $\left(C_{5}-C_{12}\right)$, and coke for the feeds LCO, PE/LCO, and PP/ LCO and for the catalysts A-C. When these results are evaluated, it must be taken into account that the LCO is made up of 30 wt \% of hydrocarbons with a boiling point around that of gasoline.

The results of Table 3 show that the conversion of LCO follows a given order (for the maximum conversion, 
which is obtained at $550^{\circ} \mathrm{C}$ ): catalyst $\mathrm{B}>$ catalyst $\mathrm{C}>$ catalyst $\mathrm{A}$. This order does not correspond to the total acidity, to the surface area, or to the average diameter of the zeolite micropores. These results are explained by the existence of a compromise between the amount and strength of the acid sites and by the accessibility of the reactants to these sites. Techniques such as catalyst steaming, which favor the accessibility to the acid sites, provoke unavoidable deterioration in acidity. Nevertheless, the high conversion that is obtained with catalyst $C$, al though its acidity is low, is evidence of the important role of accessibility for a reaction of heavy compounds such as those of LCO.

Moreover, for the three catalysts, the conversion increases as the temperature is increased, approximately 3 wt \% from 450 to $550^{\circ} \mathrm{C}$ for catalysts B and C and slightly less for catalyst $\mathrm{A}$.

The yield of the $C_{5}-C_{12}$ fraction obtained from LCO is high for the three catalysts and follows an order that is in agreement with the surface area, especially at low temperatures. Catalyst $\mathrm{A}$ has the largest surface area and, consequently, its acid site density is moderate (suitable for limiting coke generation). Catalyst B is of high acidity and lower surface area and has high acid site density, generating a higher yield of coke. Catalyst $\mathrm{C}$ is less active than the previous ones at $450^{\circ} \mathrm{C}$, but its coke yield is slightly lower than that of $\mathrm{A}$ at low temperatures. These results are evidence of the great significance of the accessibility of the zeolite channels, which is the limiting step in the cracking of heavy feeds. Likewise, acidity is also important in coke deposition, which limits the yield of interesting products. The effect of temperature is similar for the three catalysts. As the temperature is increased, the yield of the gasoline pool $\left(C_{5}-C_{12}\right)$ decreases and those of $C_{1}$ and $C_{2}$ gases, $C_{3}$ and $\mathrm{C}_{4}$ gases, and coke increase.

When the results shown in Table 3 of conversion of the PE/LCO and PP/LCO blends are compared, it is observed that, in general, the conversion is similar to that obtained for LCO, although under certain conditions it is slightly lower for the blends. Thus, the conversion for the PE/LCO blend is slightly lower than that corresponding to LCO with catalyst A in the 450$525^{\circ} \mathrm{C}$ range. The conversion of the PP/LCO blend at $450^{\circ} \mathrm{C}$ is lower than that of LCO, for the three catalysts.

As the temperature is increased, the conversion of the blends increases significantly. The conversion of the $\mathrm{PE} / \mathrm{LCO}$ blend at $550^{\circ} \mathrm{C}$ is very similar to that of LCO, whereas that of the PP/LCO blend is notably higher. When the product distribution is analyzed, it is observed that this increase is a consequence of coke formation from PP, especially for catalyst B, which is more acidic.

Comparison of the Catalysts. Figures 3 and 4 show the effect of temperature on the sel ectivity of the pools of gasoline $\left(\mathrm{C}_{5}-\mathrm{C}_{12}\right)$ and coke, respectively, for the three catalysts. Each graph corresponds to a feed. The selectivity has been calculated as

$$
\begin{aligned}
& \text { selectivity of lump } \mathrm{i}= \\
& \qquad \frac{\text { mass of lump } \mathrm{i}}{\text { total mass of the products }} \times 100
\end{aligned}
$$

In Figure 3, it is observed that the selectivity to gasoline decreases as the temperature is increased for all of the catalysts and feeds. When the selectivity to gasoline in the cracking of LCO is compared for the three catalysts (Figure 3a), the following order is observed: $A>C>B$. This order shows that the porous
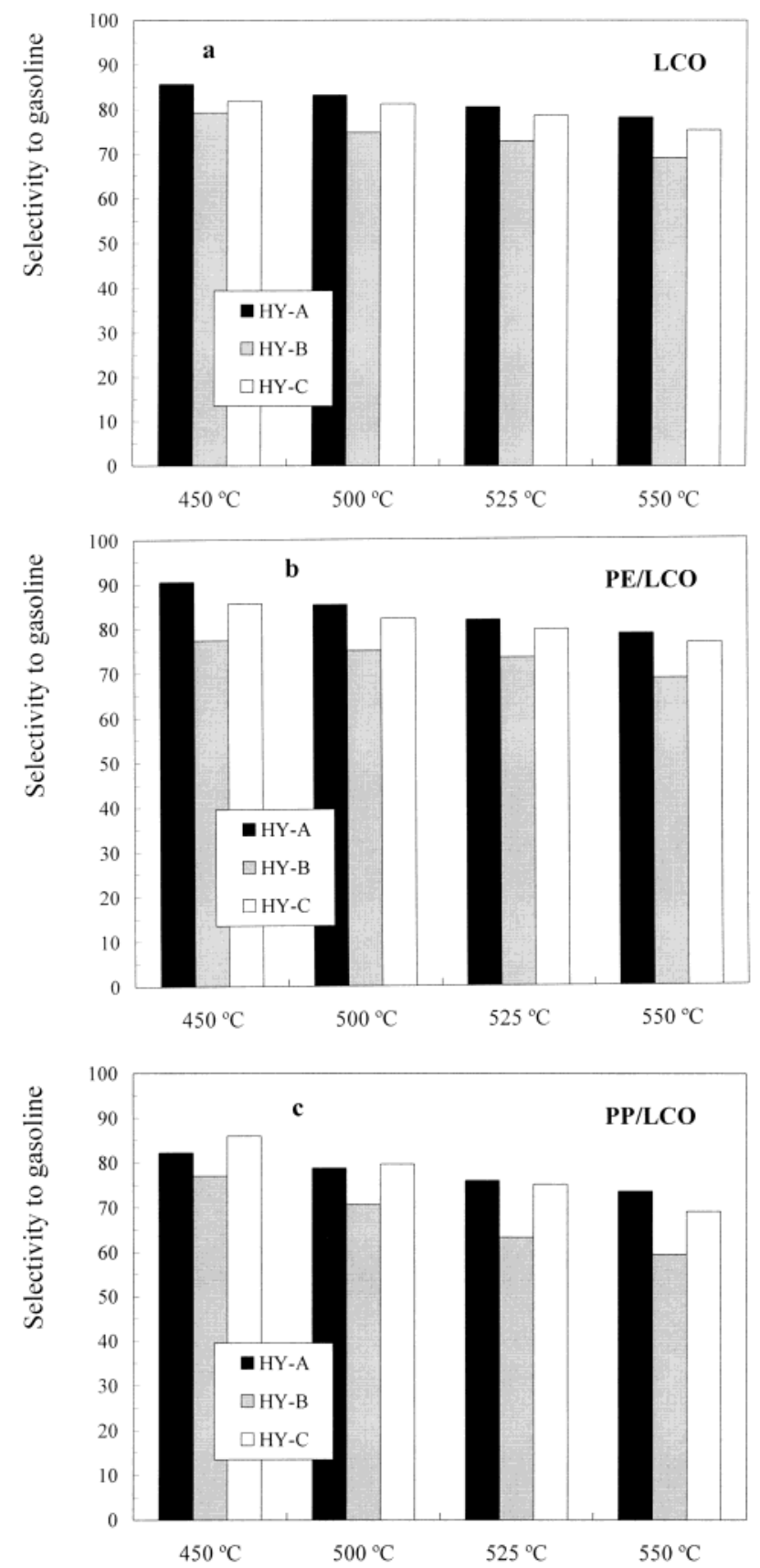

Figure 3. Effect of the temperature on the selectivity of the pool of gasoline $\left(\mathrm{C}_{5}-\mathrm{C}_{12}\right)$ for the three catalysts: (a) cracking of LCO; (b) cracking of PE/LCO; (c) cracking of PP/LCO.

structure is more important than the acidity for the cracking of heavy feeds. Table 1 shows that catalyst A has the largest surface area, which is mainly due to micropores, whereas catalyst $\mathrm{C}$, which is of much lower acidity than the other two catalysts, has a porous structure in which the micropores are slightly greater ( $9.9 \AA$ of average diameter in catalyst $C$ and $9.3 \AA$ in catalyst A). Furthermore, the steaming treatment has generated mesopores of $40 \AA$ in catalyst C, which facilitates the accessibility of the components of LCO to the acid sites of the zeolite. Lee et al. obtained a similar porous structure by severe steaming of a $\mathrm{HY}$ zeol ite. ${ }^{40}$

The cracking of the PE/LCO blend (Figure $3 b$ ) on catalysts $A$ and $C$ provides a higher selectivity to gasoline at $450{ }^{\circ} \mathrm{C}$ than that corresponding to the cracking of LCO, although this positive effect of feeding 

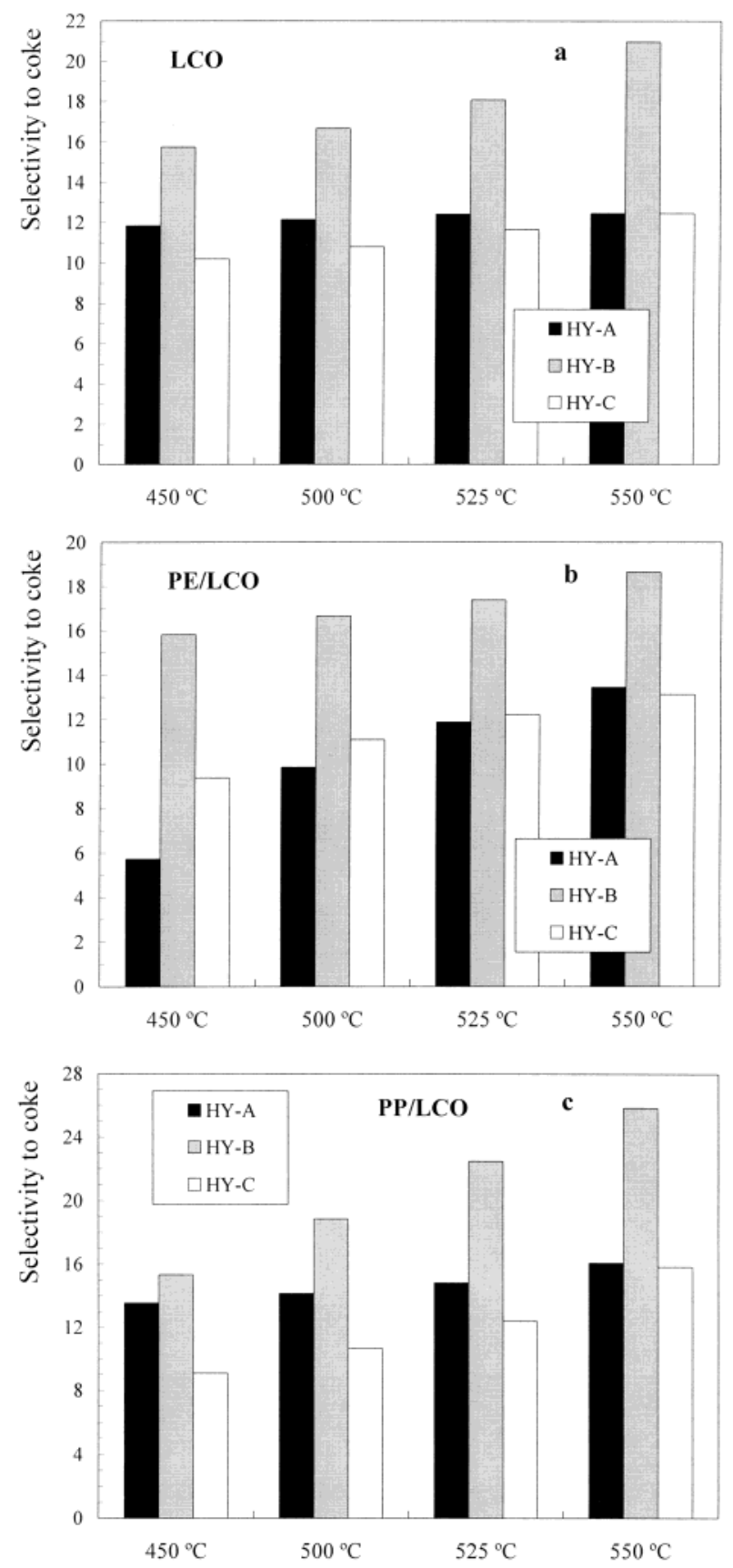

Figure 4. Effect of the temperature on the selectivity to coke for the three catalysts: (a) cracking of LCO; (b) cracking of PE/LCO; (c) cracking of PP/LCO.

PE is attenuated as the cracking temperature is increased. The effect of the catalyst properties is that mentioned earlier for the results obtained in the cracking of LCO, although a better performance of catalyst $C$ is noteworthy. This is evidence of the greater importance of accessibility to the pores in the cracking of this blend. This effect of accessibility is even more pronounced in the cracking of PP/LCO, in which the higher selectivity to gasol ine corresponds to catalyst $C$ at 450 and $500{ }^{\circ} \mathrm{C}$. This result is coherent with the hypothesis of diffusional control, which attenuates as the temperature is increased because of the lower adsorption rate of the reactants on the acid sites and the increase in the effective diffusion coefficient.

The high activity of catalyst $\mathrm{C}$ for conversion of the blends may, to a large extent, be due to the low coke
Table 4. Composition of the Pool of $C_{5}-C_{12}$, Obtained in the Cracking of LCO, PE/LCO, and PP/LCO

\begin{tabular}{lcccccc}
\hline feedstock & $\mathrm{T},{ }^{\circ} \mathrm{C}$ & n-paraffins & i-paraffins & olefins & naphthenes & aromatics \\
\hline LCO & 450 & 4.58 & 6.27 & 6.72 & 2.38 & 80.05 \\
& 500 & 4.54 & 6.04 & 6.92 & 2.34 & 80.16 \\
& 525 & 4.50 & 5.94 & 7.21 & 2.15 & 80.20 \\
& 550 & 4.19 & 5.91 & 7.68 & 1.71 & 80.51 \\
PE/LCO & 450 & 3.34 & 3.79 & 6.09 & 1.91 & 84.87 \\
& 500 & 4.27 & 3.83 & 8.00 & 1.91 & 81.99 \\
& 525 & 4.58 & 3.87 & 8.25 & 2.05 & 81.25 \\
& 550 & 4.61 & 3.89 & 9.01 & 2.13 & 80.36 \\
PP/LCO & 450 & 3.21 & 4.81 & 6.33 & 1.89 & 83.76 \\
& 500 & 3.12 & 4.51 & 7.53 & 1.88 & 82.96 \\
& 525 & 3.10 & 4.37 & 7.83 & 1.76 & 82.94 \\
& 550 & 2.96 & 3.31 & 9.42 & 1.49 & 82.82
\end{tabular}

deposition, which will provoke a lower limitation than in the other catalysts to the diffusion of the macromolecular chains of the plastics within the porous structure.

The results of selectivity to coke shown in Figure 4 are coherent with those mentioned above for sel ectivity to gasoline. First, the selectivity to coke increases as the temperature is raised for all of the feeds and catalysts. Furthermore, for each catalyst the selectivity to coke generally follows the order PP/LCO > LCO > $\mathrm{PE} / \mathrm{LCO}$. The higher selectivity to coke of catalyst $\mathrm{B}$ is evident for the three feeds, whereas for the other two catalysts, the order in the selectivity to coke depends on the feed and temperature. Nevertheless, a good performance (low sel ectivity to coke) of catalyst $\mathrm{C}$ at low temperatures $\left(450\right.$ and $\left.500{ }^{\circ} \mathrm{C}\right)$ is noteworthy when the feed is LCO or the PP/LCO blend.

The results of selectivity to coke for the different catalysts are explained by the importance of the porous structure in coke deposition. In the $450-500{ }^{\circ} \mathrm{C}$ range, coke deposition is mainly conditioned by the diffusion of coke precursor components through the porous structure. In a microporous $Y$ zeolite without mesopores, such as catalyst B, ol igomer and monoaromatic coke precursors are retained and they evolve toward polymeric structures that make up coke. ${ }^{41}$ This coke evolution is activated mainly by strongly acidic sites and is favored by a high surface density of acid sites. ${ }^{42-44}$

Furthermore, a high capacity is emphasized in the literature for the formation of coke from propylene (main product in the cracking of PP) by oligomerization, Diels-Alder mechanisms of formation of aromatics, and their condensation. ${ }^{41,45}$ Ethylene (primary product in the cracking of PE) is less active in these intermediate steps of coke formation but is more active in alkylation reactions, which attenuate the evolution of coke and contribute to the hydrogenation of the cracking products.

Composition of the Gasoline Fraction $\left(\mathrm{C}_{5}-\mathrm{C}_{12}\right)$. Table 4 shows the composition of the $\mathrm{C}_{5}-\mathrm{C}_{12}$ gasoline pool, obtained in the cracking of LCO, PE/LCO, and $\mathrm{PP} / \mathrm{LCO}$. The results correspond to catalyst $\mathrm{A}$. The results corresponding to the other catalysts are qualitatively similar.

The content of aromatics of the $\mathrm{C}_{5}-\mathrm{C}_{12}$ pool obtained in the cracking of LCO is high, around 80 wt \% at 450 ${ }^{\circ} \mathrm{C}$ and almost independent of temperature. The presence of plastics in the feed notably increases this content of aromatics. The content of aromatics in the cracking of PE/LCO decreases as the temperature is increased from 85 wt $\%$ at $450{ }^{\circ} \mathrm{C}$ to 80 wt $\%$ at $550{ }^{\circ} \mathrm{C}$, approximately. For the cracking of PP/LCO, the effect of temperature is lower and the content of aromatics is approximately between 84 and 83 wt \%. A further 

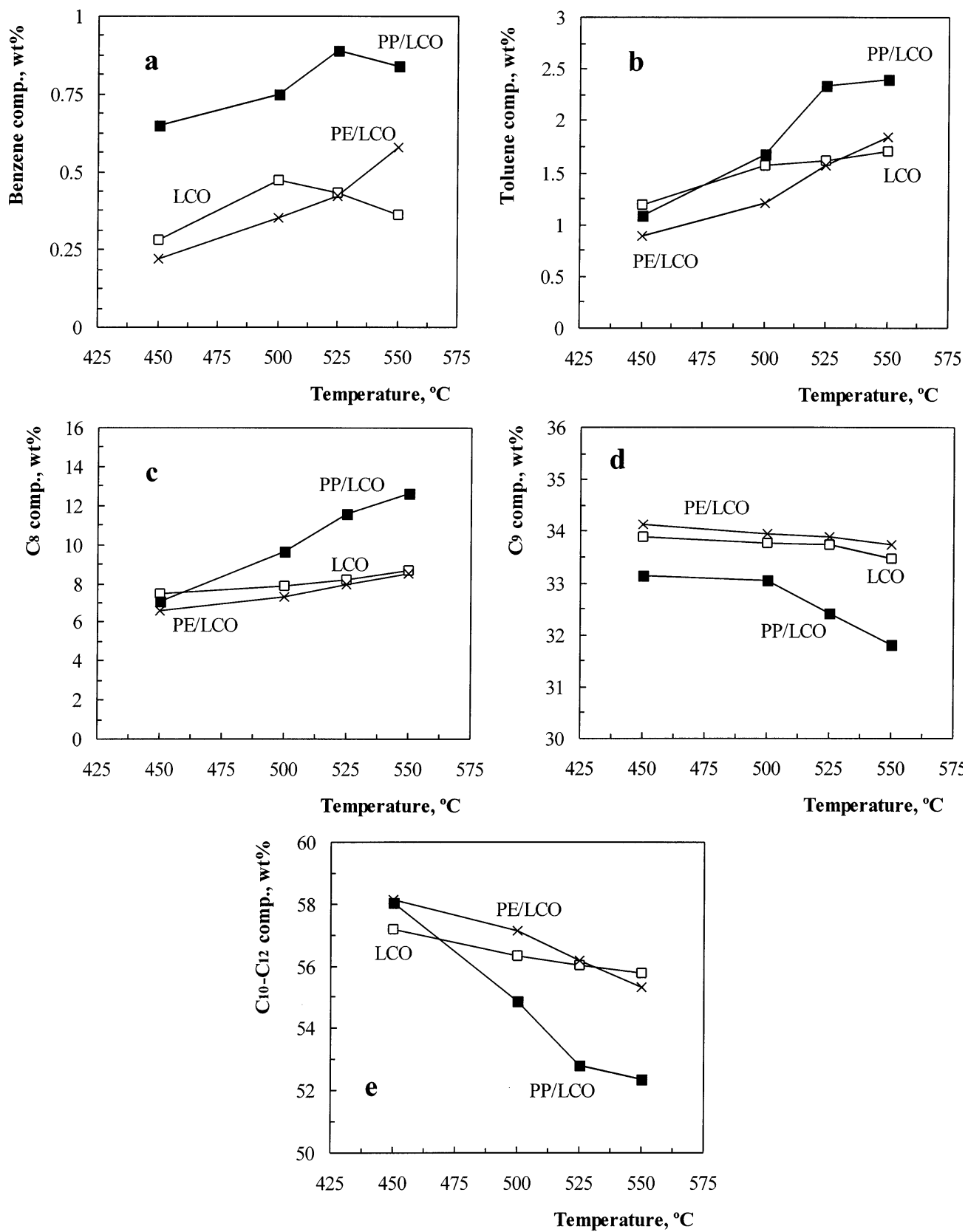

Figure 5. Effect of the temperature on the composition, in wt \%, of the different components and lumps of the fraction of aromatics of the pool of gasoline $\left(C_{5}-C_{12}\right)$ in the cracking of the three feeds on catalyst $A$ : (a) benzene; (b) toluene; (c) $C_{8}$ fraction; (d) $C_{9}$ fraction; (e) $\mathrm{C}_{10}-\mathrm{C}_{12}$ fraction.

characteristic of the pool of gasoline obtained from the cracking of the blends is the higher content of olefins than that obtained from the cracking of LCO.

These results are evidence of the capacity of the Brönsted sites of the $Y$ zeolite for the reactions of ol igomerization and Diels-Alder condensation of light ol efins, which are the primary products of the cracking of $\mathrm{PE}$ and $\mathrm{PP}$.

Because of the important aromatic content of the $\mathrm{C}_{5}-\mathrm{C}_{12}$ pool, the potential interest for valorization of the blends studied in this paper lies in the use of their aromatics, whose commercial interest is estimated to grow over the next decade, except for that of toluene. ${ }^{46}$ Figure 5 shows the effect of temperature on the composition, in weight percent, of different components and lumps of the fraction of aromatics of the $\mathrm{C}_{5}-\mathrm{C}_{12}$ pool obtained in the cracking of the three feeds. The results correspond to catalyst $\mathrm{A}$.
In graphs $a$ and $b$ of Figure 5 , it is observed that the content of benzene (Figure $5 \mathrm{a}$ ) increases with the temperature for the cracking of PE/LCO and passes through a maximun for the cracking of $\mathrm{LCO}$ and of PP/LCO. The content of toluene (Figure $5 b$ ) increases with the temperature for the three feeds. Feeding PE and PP contributes to an important increase in the concentration of these aromatics at $550{ }^{\circ} \mathrm{C}$.

In the case of $\mathrm{C}_{8}$ fraction (Figure $5 \mathrm{C}$ ), the concentration also increases with temperature and is higher in the product obtained in the cracking of dissolved PP. In the cracking of LCO, this fraction is made up mainly (>80 wt $\%$ of the total $C_{8}$ ) of xylenes and, to a lesser extent, of ethylbenzene and styrene, which are in a similar proportion.

The content of $\mathrm{C}_{9}$ aromatics is lower in the product obtained in the cracking of dissolved PP than in the cracking of PE/LCO and of LCO (Figure $5 d$ ). 

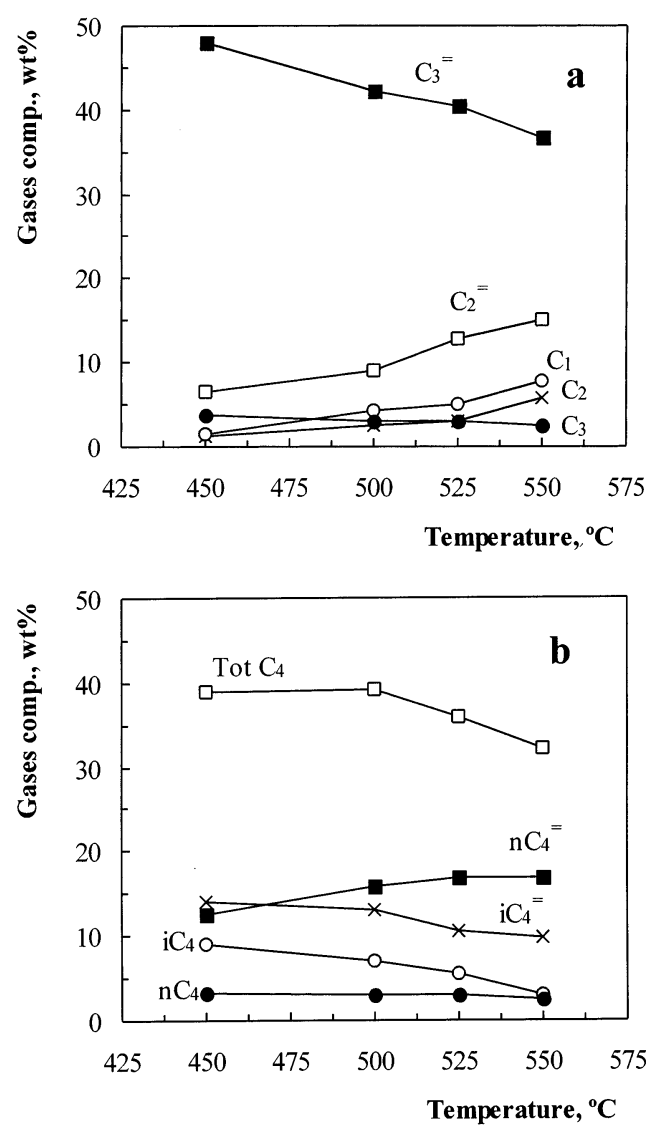

Figure 6. Effect of the temperature on the composition of the pool of gases in the cracking of LCO: (a) $C_{1}-C_{3}$ fraction; (b) $C_{4}$ fraction.

The result obtained for the composition of the $\mathrm{C}_{10}-\mathrm{C}_{12}$ aromatic fraction (F igure $5 \mathrm{e}$ ) shows that at 450 and $500{ }^{\circ} \mathrm{C}$ the cracking of dissolved PE contributes to an increase in this fraction with respect to that of the cracking of LCO. This result and those corresponding to the other graphs of Figure 5 must be interpreted on the basis of the capacity of the radicals produced in the primary cracking of the polyol efins for reacting with the heavy products of LCO or with those of its cracking. It may be expected that the aromatics $C_{9}$ and $C_{10}-C_{12}$ are mainly produced by the mechanisms of alkylationhydrogenation of the aromatic molecules contained in the LCO feed.

Composition of the Gases. Figures 6-8 show the effect of the temperature on the composition of the pool of gases, for each one of the feeds. In Figure 6, corresponding to the cracking of LCO, it is observed that at $450{ }^{\circ} \mathrm{C}$ the $\mathrm{C}_{1}-\mathrm{C}_{3}$ fraction (Figure $6 \mathrm{a}$ ) is made up mainly of propylene and that, as the temperature is increased, the concentration of ethylene increases and the concentrations of the gaseous paraffins are maintained at low values. This increase in the concentration of ethylene is a consequence of the cracking of $\mathrm{C}_{4}$ gaseous components, especially isobutene and isobutane (Figure 6b).

In the $C_{1}-C_{3}$ fraction of the gas obtained in the cracking of PE/LCO (Figure 7a), the concentrations of ethylene and propylene are almost equal to those corresponding to the cracking of LCO (Figure 6a). The concentration of ethylene increases with temperature, partially because of the cracking of the $\mathrm{C}_{4}$ fraction, whose concentration at $450{ }^{\circ} \mathrm{C}$ is significantly higher than that corresponding to the cracking of LCO, de-
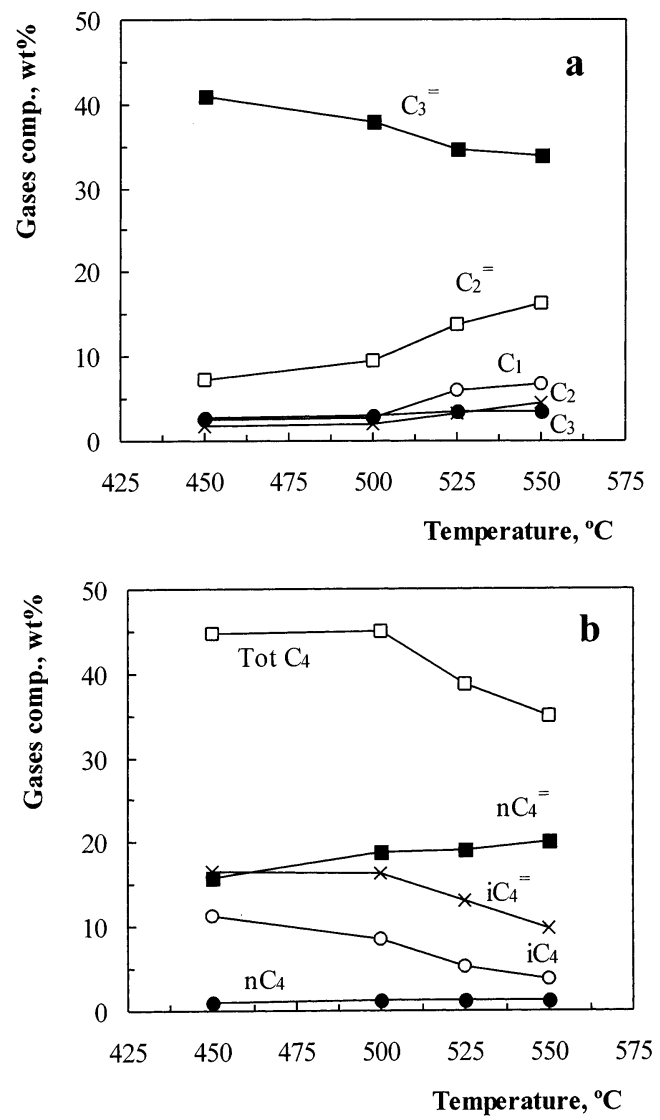

Figure 7. Effect of the temperature on the composition of the pool of gases in the cracking of PE/LCO: (a) $\mathrm{C}_{1}-\mathrm{C}_{3}$ fraction; (b) $\mathrm{C}_{4}$ fraction.

creasing as the temperature is increased, as is shown in Figure $7 \mathrm{~b}$.

In the cracking of PP/LCO (Figure 8), the concentrations of the gases $C_{1}-C_{4}$ are similar to those obtained in the cracking of PE/LCO.

As a general conclusion drawn from Figures 6-8, the high content of propylene and butenes in the stream of gases obtained in the catalytic cracking of dissolved plastics is noteworthy.

\section{Conclusions}

The catalytic cracking of polyol efins dissolved in LCO on catalysts prepared based on HY zeolites is a technology that has no additional problems to those of the catalytic cracking of the fraction used as the solvent (LCO in this paper). This technology is applicable in current FCC refinery units and avoids the problems of the pyrolysis of solid plastic wastes, such as the limitations to heat transfer and the stickiness of the fused plastic.

The maximum yield of the gasoline fraction and the lowest coke deposition is obtained at $450{ }^{\circ} \mathrm{C}$, which is also the temperature corresponding to the maximum cracking rate of polyolefins. The gasoline has a high concentration of aromatics (higher than 80 wt \%), and the gases are mainly propylene and butenes.

The properties of the catalyst have great importance. The determining factor of the good performance of the catalyst (high yield of gasoline and low yield of coke) is the porous structure, in which the existence of mesopores facilitates the diffusion of macromolecular chains to the acid sites. It has been proven that the catalyst 

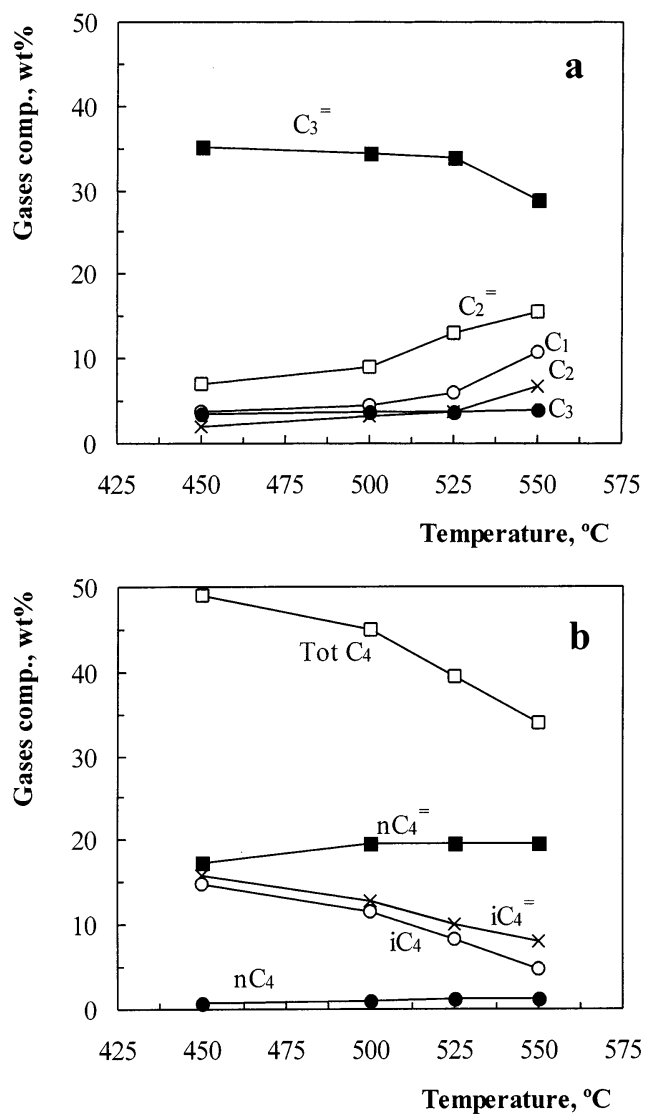

Figure 8. Effect of the temperature on the composition of the pool of gases in the cracking of PP/LCO: (a) $\mathrm{C}_{1}-\mathrm{C}_{3}$ fraction; (b) $\mathrm{C}_{4}$ fraction.

does not need a high level of surface acidity in order to be active in this process. F urthermore, a zeol ite of a high level of acidity produces a high yield of coke, especially when the dissolved plastic is PP. The presence of dissolved PE decreases the yield of coke with respect to that produced in the cracking of the solvent, whereas feeding PP contributes to the increase of the formation of coke.

\section{Acknowledgment}

This work was carried out with the financial support of the University of the Basque Country (Project 9/UPV 00069.310-13607/2001) and of the Ministry of Science and Technology of the Spanish Government (Project PPQ2000-1286). We are indebted to Petronor SA and Dow Chemical SA for their generous provision of materials.

\section{Literature Cited}

(1) Sasse, F.; Emig, G. Chemical Recycling of Polymer Materials. Chem. Eng. Technol. 1998, 21, 777.

(2) Kaminsky, W.; Hartmann, F. New Pathways in Plastics Recycling. Angew. Chem., Int. Ed. 2000, 39, 331.

(3) Scott, D. S.; Czernik, S. R.; Piskorz, J .; Radlein, A. G. Fast Pyrolysis of Plastic Wastes. Energy Fuels 1990, 4, 407.

(4) Kaminsky, W. Possibilities and Limits of Pyrolysis. Makromol. Chem., Macromol. Symp. 1992, 57, 145.

(5) Kaminsky, W.; Schlesselmann, B.; Simon, C.J . Olefins from Polyolefins and Mixed Plastics by Pyrolysis. J. Anal. Appl. Pyrolysis 1995, 32, 19.

(6) Conesa, J . A.; Font, R.; Marcilla, A.; García, A. N. Pyrolysis of Polyethylene in a Fluidized Bed Reactor. Energy Fuels 1994, 8 , 1238.
(7) Conesa, J . A.; Font, R.; Marcilla, A. Comparison between the Pyrolysis of Types of Polyethylenes in a Fluidized Bed Reactor. Energy Fuels 1997, 11, 126.

(8) Williams, P. T.; Williams, E. A. Fluidized Bed Pyrolysis of Low Density Polyethylene to Produce Petrochemical Feedstock. J . Anal. Appl. Pyrolysis 1999, 51, 107.

(9) Mastral, F.J .; Esperanza, E.; García, P.; J uste, M. Pyrolysis of High-Density Polyethylene in a Fluidised Bed Reactor. I nfluence of the Temperature and Residence Time. J . Anal. Appl. Pyrolysis 2002, 63, 1 .

(10) Sodero, S. F.; Berruti, F.; Behie, L. A. Ultrapyrolytic Cracking of Polyethylene. A High Yield Recycling Method. Chem. Eng. Sci. 1996, 51, 2805

(11) Lovett, S.; Berruti, F.; Behie, L. A. Ultrapyrolytic U pgrading of Plastics Wastes and Plastics/Heavy Oil Mixtures to Valuable Light Gas Products. Ind. Eng. Chem. Res. 1997, 36, 4436.

(12) Westerhout, R. W. J .; Waanders, J .; Kuipers, J . A. M.; van Swaaij, W. P. M. Development of a Continuous Rotating Cone Reactor Pilot Plant for the Pyrolysis of Polyethene and Polypropene. Ind. Eng. Chem. Res. 1998, 37, 2316.

(13) Westerhout, R. W. J .; Waanders, J .; Kuipers, J . A. M.; van Swaaij, W. P. M. Recycling of Polyethene and Polypropene in a Novel Bench-Scale Rotating Cone Reactor by High-Temperature Pyrolysis. Ind. Eng. Chem. Res. 1998, 37, 2293.

(14) Bockhorn, H.; Hentschel, J .; Hornung, A.; Hornung, U. Environmental Engineering Stepwise Pyrolysis of Plastic Waste. Chem. Eng. Sci. 1999, 54, 3043.

(15) Schirmer, J .; Kim, J. S.; Klemm, E. Catalytic Degradation of PolyethyleneUsing Thermal Gravimetric Analysis and a CycledSpheres-Reactor. J . Anal. Appl. Pyrolysis 2001, 60, 205.

(16) Masuda, T.; Kushino, T.; Matsuda, T.; Mukai, S. R.; Hashimoto, K.; Y oshida, S. Chemical Recycling of Mixture of Waste Plastics Using a New Reactor System with Stirred Heat Medium Particles on Steam Atmosphere. Chem. Eng. J . 2001, 82, 173.

(17) Serrano, D. P.; Aguado, J .; Escola, J . M.; Garagorri, E. Conversion of Low-Density Polyethylene into Petrochemical Feedstocks Using a Continuous Screw Kiln Reactor. J. Anal. Appl. Pyrolysis 2001, 58-59, 789.

(18) Aguado, R.; Olazar, M.; Gaisán, B.; Prieto, R.; Bilbao, J. Kinetic Study of Polyolefins Pyrolysis in a Conical Spouted Bed Reactor. Ind. Eng. Chem. Res. 2002, 41, 4559.

(19) Aguado, R.; Olazar, M.; San J osé, M. J .; Gaisán, B.; Bilbao, J. Wax Formation in the Pyrolysis of Polyolefins in a Conical Spouted Bed Reactor. Energy Fuels 2002, 16, 1429-1437.

(20) Sharratt, P. N.; Lin, Y. H.; Garforth, A. A.; Dwyer, J . Investigation of the Catalytic Pyrolysis of High-Density Polyethylene over a HZSM-5 Catalyst in a Laboratory Fluidized-Bed Reactor. Ind. Eng. Chem. Res. 1997, 36, 5118.

(21) Lin, Y. H.; Sharratt, P. N.; Garforth, A. A.; Dwyer, J. Catalytic Conversion of Polyolefins to Chemicals and Fuels over Various Cracking Catalysts. Energy Fuels 1998, 12, 767.

(22) Ali, S.; Garforth, A. A.; Harris, D. H.; Rawlence, D. J .; Uemichi, Y. Polymer Waste Recycling over "Used" Catalysts. Catal. Today 2002, 75, 247.

(23) Harding, R. H.; Peters, A. W.; Nee, J . R. D. New Developments in FCC Catalyst Technology. Appl. Catal. 2001, 221, 389.

(24) Songip, A. R.; Masuda, T.; Kuwahara, H.; Hashimoto, K. Test to Screen Catalysis for Reforming Heavy Oil from Waste Plastics. Appl. Catal. B 1993, 2, 153

(25) Songip, A. R.; Masuda, T.; Kuwahara, H.; Hashimoto, K. Kinetic Studies for Catalytic Cracking of Heavy Oil from Waste Plastics over REY Zeolite. Energy Fuels 1994, 8, 131.

(26) Songip, A. R.; Masuda, T.; Kuwahara, H.; Hashimoto, K. Production of High-Quality Gasoline by Catalytic Cracking over Rare-Earth Metal Exchanged Y-Type Zeolites of Heavy Oil from Waste Plastics. Energy Fuels 1994, 8, 136

(27) $\mathrm{Ng}, \mathrm{S}$. H. Conversion of Polyethylene to Transportation Fuels through Pyrolysis and Catalytic Cracking. Energy Fuels 1995, 9, 735.

(28) Ng, S. H. Conversion of Polyethylene Blended with VGO to Transportation Fuels by Catalytic Cracking. Energy Fuels 1995 9, 216.

(29) Arandes, J. M.; Abajo, I.; López-Valerio, D.; Fernández, I.; Azkoiti, M. J .; Olazar, M.; Bilbao, J . Transformation into Fuels of Several Plastic Wastes by Catalytic Cracking. Ind. Eng. Chem. Res. 1997, 36, 4523.

(30) Piel, W. J . Transportation Fuels of the Future. Fuel Proc. Technol. 2001, 71, 167. 
(31) Sakata, Y.; Uddin, M. A.; Muto, A. Degradation of Polyethylene and Polypropylene into Fuel Oil by Using Solid Acid and non-Acid Catalysts. J . Anal. Appl. Pyrolysis 1999, 51, 135.

(32) Hesse, N.; Lin, R.; Bonnet, E.; Cooper, J ., III.; White, R. L. In Situ Analysis of Volatiles Obtained from the Catalytic Cracking of Polyethylene. J . Appl. Polym. Sci. 2001, 82, 3118.

(33) Han, S.; Shihabi, D. S.; Chang, C. D. Selective Removal of Surface Acidity in ZSM-5 Zeolite Using $\left(\mathrm{NH}_{4}\right)_{2} \mathrm{SiF}_{6}$ Treatment. J . Catal. 2000, 196, 375

(34) Aguayo, A. T.; Benito, P. L.; Gayubo, A. G.; Olazar, M.; Bilbao, J. Acidity Deterioration and Coke Deposition in a H-ZSM-5 Zeolite in the MTG Process. Stud. Surf. Sci. Catal. 1994, 88, 567.

(35) Aquayo, A. T.; Gayubo, A. G.; Ereña, J.; Olazar, M. Arandes, J. M.; Bilbao, J. I sotherms of Chemical Adsorption of Bases on Solid Catalysts for Acidity Measurement. J. Chem. Technol. Biotechnol. 1994, 60, 141.

(36) Sedran, U. Laboratory Testing of FCC Catalysts and Hydrogen Transfer Properties Evaluation. Catal. Rev. Sci. Eng. 1994, 36, 405

(37) de Lasa, H. I. Riser Simulator for Catalytic Cracking Studies. U.S. Patent 5,102,628, 1992.

(38) Arandes, J . M.; Abajo, I.; Fernández, I.; López, D.; Bilbao, $\mathrm{J}$. Kinetics of Gaseous Product F ormation in the Coke Combustion of a Fluidized Catalytic Cracking Catalyst. Ind. Eng. Chem. Res. 1999, 38, 3255

(39) Arandes, J. M.; Abajo, I.; Fernández, I.; Azkoiti, M. J .; Bilbao, J. Effect of HZSM-5 Zeolite Addition to a FCC Catalyst. Study in a Laboratory Reactor Operating under Industrial Conditions. Ind. Eng. Chem. Res. 2000, 39, 1917.
(40) Lee, K. H.; Ha, B. H.; Lee, Y. W. Catalytic Cracking of Vacuum Gas Oil over the Modified Mordenites and Y-Type Zeolites Mixed with Alumina. Ind. Eng. Chem. Res. 1998, 37, 1761.

(41) Guisnet, M.; Magnoux, P. Organic Chemistry of Coke Formation. Appl. Catal. 2001, 212, 83.

(42) Corma, A.; Martínez, A.; Martínez-Soria, V.; Monton, J . B. Hydrocracking of Vacuum Gas Oil on the Novel Mesoporous MCM-41 Aluminosilicate Catalysts. J . Catal. 1995, 153, 25.

(43) Corma, A.; Grande, M. S.; González-Alfaro, V.; Orchilles, A. V. Cracking Activity and Hydrothermal Stability of MCM-41 and its Comparison with Amorphous Silica-Alumina and a USY Zeolite. J . Catal. 1996, 159, 375.

(44) Al-Khattaf, S. The Influence of Y-Zeolite Unit Cell Size on the Performance of FCC Catalysts During Gas Oil Catalytic Cracking. Appl. Catal. 2002, 231, 293.

(45) Dimon, B.; Cartraud, P.; Magnoux, P.; Guisnet, M. Coking, Aging and Regeneration of Zeolites. XIV. Kinetic Study of the Formation of Coke from Propene over USHY and H-ZSM-5. Appl. Catal. 1993, 101, 351.

(46) Weitkamp, J .; Raichle, A.; Tra, Y. Novel Zeolite Catalysis to Create Value from Surplus Aromatics: Preparation of $\mathrm{C}_{2+}-\mathrm{n}$ alkanes, a High-quality Synthetic Steamcracker F eedstock. Appl. Catal. 2001, 222, 277.

Received for review December 9, 2002 Revised manuscript received May 29, 2003 Accepted J une 3, 2003

IE020986G 